\title{
Methods of improving power indices of electric drive active rectifiers for mine hoists
}

\author{
Oleg Sinchuk ${ }^{1}$, Yulii Filipp ${ }^{1}$, Albert Somochkyn ${ }^{1}$, Ryszard Strzelecki², and Mila Baranovska ${ }^{3, *}$ \\ ${ }^{1}$ Kryvyi Rih National University, Department of Automated Electrical-Mechanical Systems in Industry and Transport, 11 Vitalii \\ Matusevysch Str., Kryvyi Rih, 50027, Ukraine \\ ${ }^{2}$ Gdańsk University of Technology, Department of Power Electronics and Electrical Machines, 11/12 Gabriela Narutowicza, 80-233 \\ Gdańsk, Poland \\ ${ }^{3}$ Kryvyi Rih National University, Electrical Mechanics Department, 11 Vitalii Matusevysch Str., Kryvyi Rih, 50027, Ukraine
}

\begin{abstract}
The research deals with analyzing peculiarities of using active rectifiers in frequency controlled electric drives of underground mine hoists. There are developed MATLAB models aimed at comparing two types of control systems - hysteresis-based and the one with pulse-width modulation. The research aims to analyze power modes and parameters of active rectifiers, quality of voltage control, current and power of active rectifiers and to determine ways of improving power indices of electric equipment of hoists as well as provide power compatibility of electric equipment and underground mines' grids. Main attention is paid to analyzing circuitry of control systems of active rectifiers, parameters of power transformers and reactor equipment at underground mines' substations, frequency converters and synchronous slow-speed motors. There are also analyzed statistic data on power consumption at underground mines equipped with automated systems of commercial and technical power meters and specific consumption of power. The research results reveal advantages of the pulse-width modulation control system as compared with the hysteresis one by using such indices as speed-performance, quality of control, potential of controlling reactive power and the power factor. Application of the research results will enable determining structures and methods of adjusting control over the active rectifier in the frequency-controlled drive of underground mine hoists.
\end{abstract}

\section{Introduction}

Kryvyi Rih iron ore basin is a large producer of iron ore and raw materials for metallurgical enterprises (pellets, sinter) not only in Ukraine, but also in post-Soviet countries. Kryvyi Rih houses the largest metallurgical works, ArcelorMittal Kryvyi Rih, four mining and concentration plants (InGZK, PivdGZK, Central GZK, PivnGZK) with open pit ore mining and Kryvyi Rih iron ore works with underground ore mining.

At Kryvyi Rih underground mines, iron ore mined possesses a higher iron content than that from open pits of the mining and concentration plants. Power consumption of ore mining and haulage from underground levels of $1300 \mathrm{~m}-1500 \mathrm{~m}$ is higher than that at $200 \mathrm{~m}-300 \mathrm{~m}$.

Four underground mines of Kryvyi Rih iron ore works (Rodina, Zaria, Hvardiiska and Ternovska), Yuvileina (Sukha Balka deposit) and the underground mine named after Artem (ArcelorMittal Kryvyi Rih) mine and hoist iron ore in Kryvyi Rih basin. Skip hoists with automated DC/AC drives perform these operations [1-3].

In the1960s-1970s, skip hoists primarily used DC drives with the Ward-Leonard drive system. This system enables required power of DC motors, smooth adjustment of mined mineral hoisting and minimal impacts of an electric drive on the main. The drawbacks of this drive system include necessity to install extra powerful large machines - a synchronous motor (SM) and a DC generator. This also involves additional maintenance expenses, increased power losses for idle performance of the generator and the DC motor, etc.

In the 1980s, there appeared powerful thyristor machines produced by Kharkiv electric-mechanical plant and Zaporizhzhia production association Preobrazovatel. This arouse the issue of applying these machines to replacing Ward-Leonard drives to increase electric drive capacity because of increased mining depth. The research institute Kryvbasproekt developed a design of modernizing some underground mines using a thyristor drive-motor (TD-M) system (Pervomaiska, the underground mine named after Lenin (Ternovska now), Yuvileina).

Practice of exploiting these drives has revealed both their efficiency and drawbacks. When reducing power consumption per a ton of mined ore, weight-size indices of electric equipment and maintenance costs, it is determined that the TD-M system impacts power quality in $6 \mathrm{kV}$ transmission grids of underground mines, their sub-consumers (municipal mains, electric transport, water treatment, etc.). This impact is revealed through voltage slumps and sinusoidal wave

* Corresponding author: mila.baranovskaya@gmail.com 
deformation when starting hoist drives, resonant phenomena when changing parameters of the supply main because of consumer switching, etc. The measures provided on the stage of electric drive designing and implementing (installation of harmonic filters) enabled partial reduction of this impact. With condensers of harmonic filters getting obsolete and broken, there appeared a problem of replacing TD-M drives of hoists by more effective ones [4-6].

AC electric drives with the FC-SM (frequency convertor-synchronous motor) and FC-AM (frequency convertor-asynchronous motor) systems came into use worldwide in the 2000s. These drive systems use AC motors which are more efficient as compared to the DC ones (smaller sizes, inertia moments, copper consumption for winding, no collector and costs for its maintenance, etc.) $[7,8]$.

Besides, application of IGBT-transistors in frequency convertors of these drive systems allows developing and improving their control algorithms aimed at ensuring the higher-order harmonic, reactive power and the power factor.

The world-leading producers of powerful frequency convertors (ABB, General Electric, Siemens, Danfoss) are engaged in improving their power indices, quality of electric power in the main, reducing weight-size indices, providing better maintenance and service, etc.

In 2011, the skip hoist drive at Ternivska underground mine was modernized in order to increase its hoist capacity from $25 \mathrm{t}$ to $35 \mathrm{t}$ and mining depth up to $1800 \mathrm{~m}$. That included replacement of the TD-M system by the FC-SM one with the frequency convertor produced by $\mathrm{ABB}$. Instead of two DC motors of the ПБК - 120/60 type, the AC motor AMZ 2500 LL 16 was installed. To supply this motor, there was installed a frequency convertor ACS 6000 with the microprocessor system of direct torque control in the main circuit of which ARU is an active rectifier, $\mathrm{CBU}$ is a unit of condensers; INU is an invertor unit.

Main advantages of the ACS 600 drive include:

- high operational characteristics;

- fast and accurate control combined with low power consumption ensures the best operational characteristics;

- control over the motor by the ACS 6000 through applying the highly effective direct torque control (DTC) method developed by ABB;

- the DTC method ensures the best dependency between torque and speed ever achieved in mediumvoltage drives, thus providing fast and smooth control in any condition;

- the ACS 6000 drive uses the latest semiconductor switch contacts IGCT (gate turnoff thyristors with control units) developed by $\mathrm{ABB}$ on the basis of their own researches;

- the network power unit for the two-quadrant work with the constant power factor of 0.96 within the whole speed range;

- the active rectifier unit for the four-quadrant work with reduced harmonic content and controlled power factor;

- the DC bus for working with one or more motors and power recuperation;
- breaking energy generated in a single motor can be conveyed to other invertors along the DC bus without feeding from the main;

- recuperation of rotation energy;

- low noise and vibrations.

Operation of the hoist drive with the frequency convertor ACS 6000 at Ternovska underground mine during 12 years has revealed efficiency of electric equipment and minimal impact on the main.

In 2016, the skip hoist of Zaria underground mine was modernized with the TD-M system replaced by the FC-SM with the frequency convertor made by $\mathrm{ABB}$ and two AC motors AMZ 2500 LL 16. To supply these motors with power, two frequency convertors ACS 6000 with the microprocessor system of direct torque control were installed. Installation of the two motors and the two convertors was caused by greater hoisting capacity (50t) and the need to increase ore mining depth.

Greater driving power deteriorated quality of electric power in grids. At the $6 \mathrm{kV}$ section of $150 / 6 \mathrm{kV}$ Oktiabrska substation, there are much more significant deviations of voltage than those at Leninska substation with the FC-SM of the skip hoist (Fig. 1).

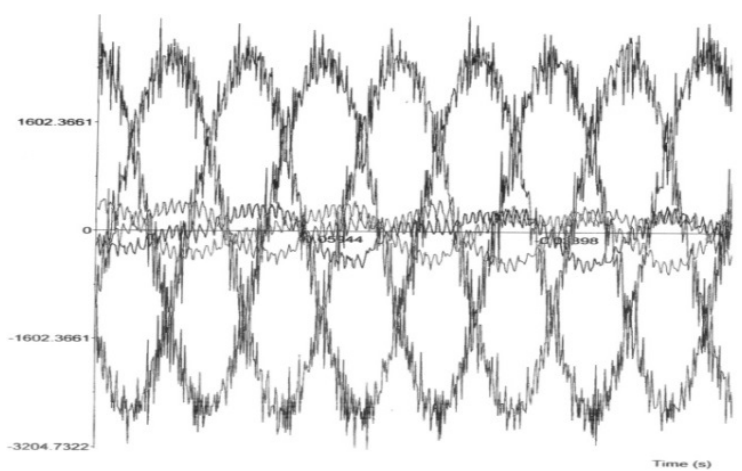

Fig. 1. Diagrams of voltage and current in the $6 \mathrm{kV}$ section.

Besides increased driving power of the skip hoist, some other factors also affect the grid including different standard capacities of power transformers at the substations (Oktiabrska - TDTN-40, Ternovska TDTN-32), the structure of power supply diagrams, presence of shunt reactors, condenser units, etc.

The single-line diagram of power supply of Kryvyi Rih iron ore works' mines includes a power transformer of the step-down substation $154 / 6 \mathrm{kV}$, a shunt reactor harmonizing the $6 / 3.1 \mathrm{kV}$ frequency convertor and a synchronous motor.

Hvardiiska underground mine is the next to upgrade its skip hoist drive. The $154 / 6 \mathrm{kV}$ substation contains two TDTN-63 transformers. Thus, in our opinion, while designing technical tasks to upgrade the drives, one should analyze their possible influence on the mains and quality of power. This analysis should consider technical potentials of active rectifiers of frequency converters. To do this, the research simulates electromagnetic processes and analyzes power quality control indices in the grid.

\section{Characteristic of the control object}

Table 1 contains data on power transformers and 
reactors of mine substations ( 1 - Ternovska, 2 - Zaria, 3 - Hvardiiska, 4 - Rodina).

Table 1. Parameters of power transformers of mine substations.

\begin{tabular}{|c|c|c|c|c|}
\hline Parameter & 1 & 2 & 3 & 4 \\
\hline Transformer type & TDTN & TRDN & TDTN & TRDN \\
\hline $\mathrm{S}_{\mathrm{H}}, \mathrm{MVA}$ & 40 & 32 & 63 & 32 \\
\hline $\mathrm{U}_{\mathrm{\kappa} 3}, \%$ & 18 & 11 & 18 & 11 \\
\hline$\Delta \mathrm{P}_{\mathrm{K} 3}, \mathrm{~kW}$ & 185 & 175 & 280 & 175 \\
\hline $\mathrm{U}_{1 \mathrm{л}}, \mathrm{kV}$ & 158 & 158 & 158 & 158 \\
\hline $\mathrm{U}_{2 \pi}, \mathrm{kV}$ & 6.6 & 6.3 & 6.6 & 6.3 \\
\hline $\mathrm{S}_{\mathrm{K} 3}, \mathrm{MVA}$ & 222 & 291 & 350 & 291 \\
\hline $\mathrm{R}_{\text {тр }}, \mathrm{Ohm}$ & 0.005 & 0.007 & 0.003 & 0.007 \\
\hline $\mathrm{X}_{\text {тр }}, \mathrm{Ohm}$ & 0.196 & 0.143 & 0.124 & 0.143 \\
\hline Reactor type & РБА & РБА & РБА & РБА \\
\hline $\mathrm{I}_{\text {nom }}$ & 2000 & 2000 & 2000 & 2000 \\
\hline $\mathrm{L}_{\mathrm{p}}, \%$ & 8 & 8 & 8 & 8 \\
\hline $\mathrm{R}_{\mathrm{p}}, \mathrm{Ohm}$ & 0.003 & 0.003 & 0.003 & 0.003 \\
\hline $\mathrm{X}_{\mathrm{p}}$, Ohm & 0.14 & 0.14 & 0.14 & 0.14 \\
\hline
\end{tabular}

Parameters of the power convertor transformer and the synchronous motor are in Table 2.

Table 2. Parameters of the convertor transformer and the synchronous motor.

\begin{tabular}{|l|c|c|}
\hline \multicolumn{1}{|c|}{ Parameter } & Transformer & Motor \\
\hline Transformer type & Resibloc & - \\
\hline $\mathrm{S}_{\mathrm{H}} \mathrm{kVA}$ & 3200 & - \\
\hline $\mathrm{U}_{1 \mathrm{I}}, \mathrm{kV}$ & 6.0 & - \\
\hline
\end{tabular}

\begin{tabular}{|l|c|c|}
\hline $\mathrm{U}_{2 \pi}, \mathrm{kV}$ & 3.15 & - \\
\hline $\mathrm{U}_{\mathrm{K} 3}, \%$ & 12 & - \\
\hline$\Delta \mathrm{P}_{\mathrm{K} 3}, \mathrm{~kW}$ & 22.61 & - \\
\hline Motor type & - & $\mathrm{AMZ} 2000$ \\
\hline $\mathrm{P}_{\mathrm{H}}, \mathrm{kW}$ & - & 3705 \\
\hline $\mathrm{U}_{\mathrm{H}}, \mathrm{kV}$ & - & 3.15 \\
\hline $\mathrm{I}_{\mathrm{H}}, \mathrm{A}$ & - & 717 \\
\hline $\mathrm{n}_{\mathrm{H}}, \mathrm{rpm}$ & - & 58 \\
\hline $\mathrm{J}, \mathrm{kg} \cdot \mathrm{m}^{2}$ & - & 55300 \\
\hline
\end{tabular}

The three-phase active rectifier and the selfcommutated voltage inverter invertor with high power indices are used in the frequency convertor. This diagram enables the power factor close to one, the DC mode and recuperation of power flow, i.e. the potential to transmit power to the mains.

\section{Simulation of operational modes}

This convertor type is similar to the self-commutated voltage inverter with the only exception that the diagram works in the rectifier mode and ensures the power factor close to one [9-16]. The key switches of the active rectifier can be controlled by the pulse-width modulation system or the hysteresis control system. Fig. 2 presents the diagram of the active rectifier model with the pulse-width control system. The control system has feedback signals along the input voltage $U_{1}$ and input current $\mathrm{I}_{1}$.

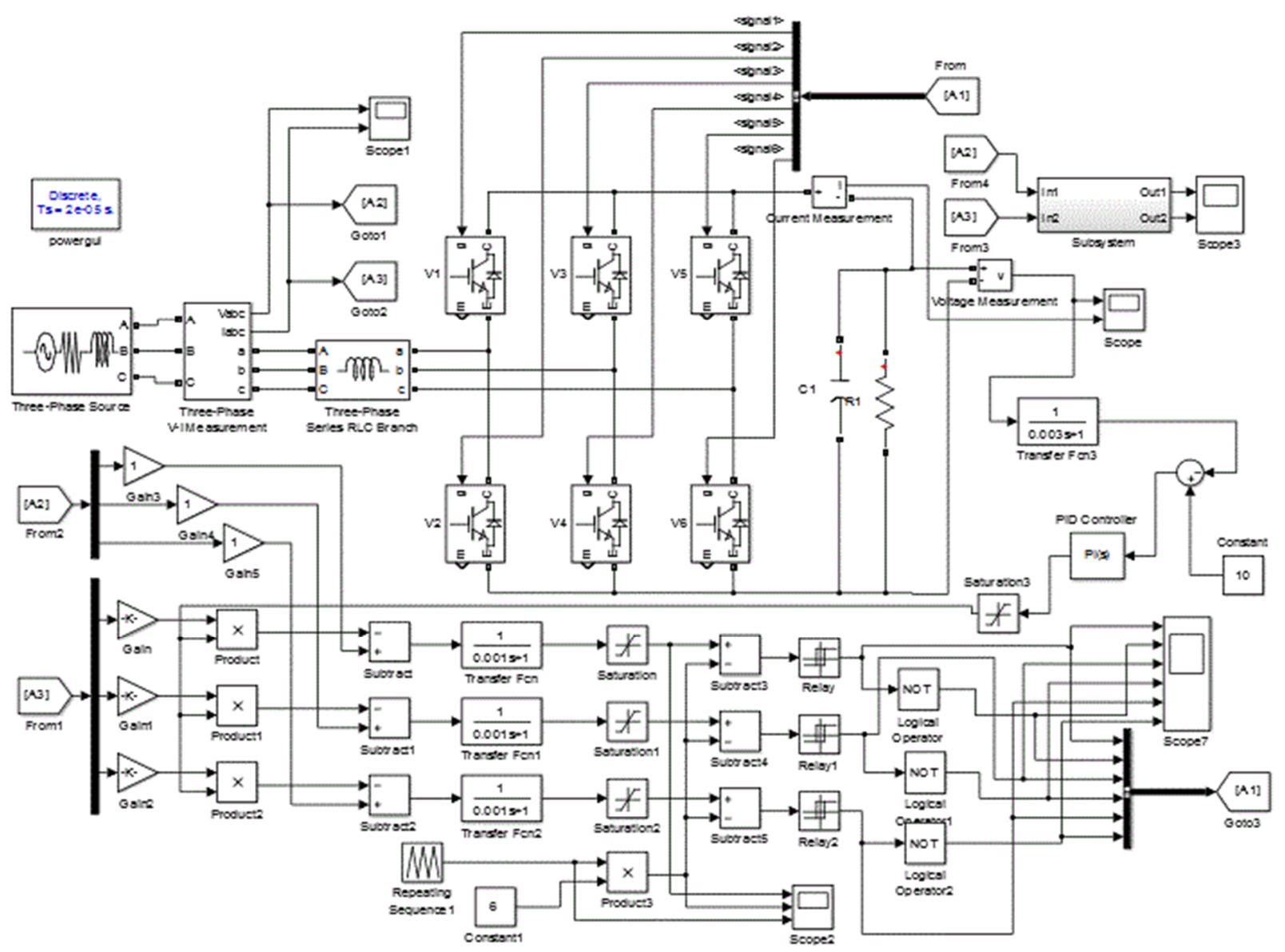

Fig. 2. Diagram of the active rectifier model with the pulse-width control system. 
Pulse-width modulation is provided by comparing the controlling signal with that of the triangle waves. There is also a proportional-integral controller of input voltage $\mathrm{U}_{\mathrm{d}}$ and a unit calculating consumed active and reactive power (Fig. 3).

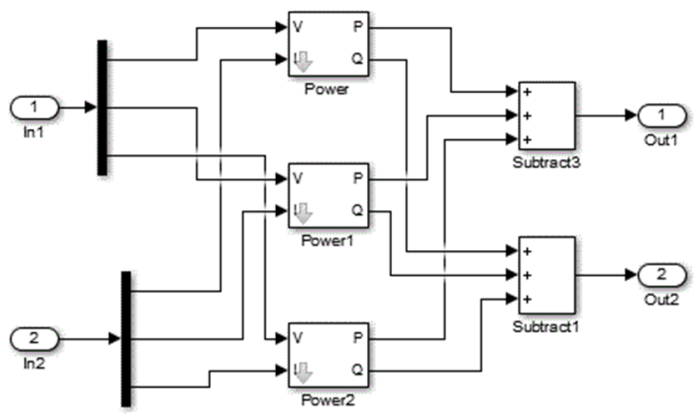

Fig. 3. Diagram of the model of calculating active and reactive power.

In simulating, dynamics of electric parameters of the active rectifier is under study. Fig. 4 shows an oscillogramme of the output current and voltage of the active rectifier.

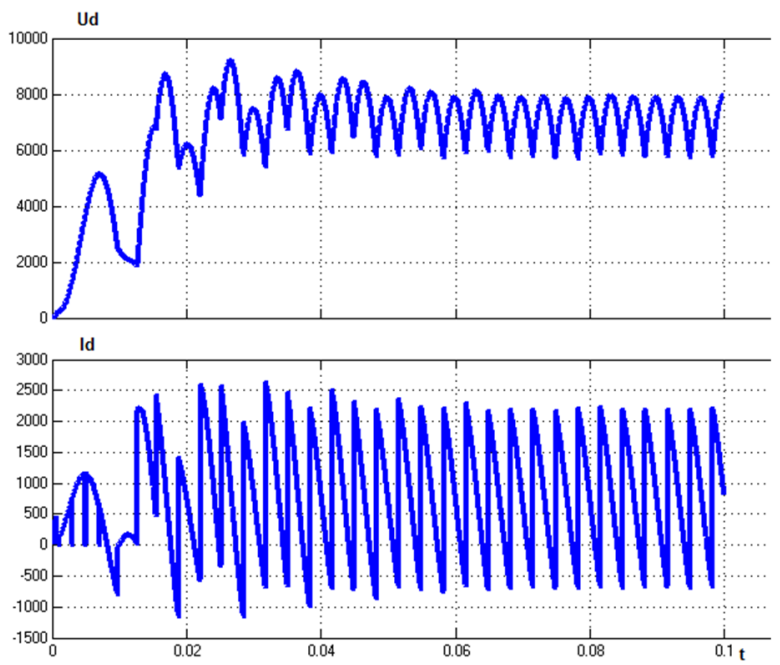

Fig. 4. Oscillogramme of the output current and voltage of the active rectifier with pulse-width modulation.

As is seen in the given diagrams, the control system enhances high-speed performance of voltage control $\left(t_{\mathrm{h}}=0.05 \div 0.06 \mathrm{c}\right)$. Fig. 5 contains diagrams of the input current and voltage of the active rectifier. As is seen, the current curve coincides in phase with that of voltage, thus providing the power factor of 1.0.

The form of the current curve is determined by the two-level active rectifier and ratio of active and inductive resistance of the power transformer of the mine substation. The time of the output voltage increase to reach the set value makes $0.02 \mathrm{sec}$, the pulse number is $\mathrm{m}=6$.

Fig. 6 shows the diagram of the active rectifier model with the hysteresis control system.

Fig. 7 contains the oscillogramme of the output current and voltage of the active rectifier, while Fig. 8 presents oscillogrammes of the input current and voltage.

As is seen from the given oscillogrammes, the voltage and current curves of the same phases are cophased, that indicating the power factor being close to one. The primary current curve of the active rectifier differs from a sinusoid and can be improved by making the rectifier diagram more complex to increase its levels.

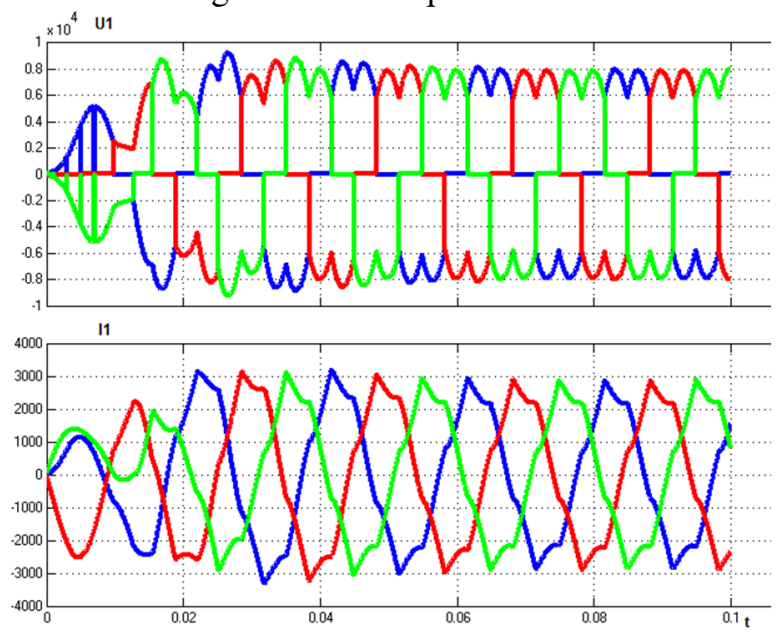

Fig. 5. Oscillogramme of the output current and voltage of the active rectifier with pulse-width modulation.
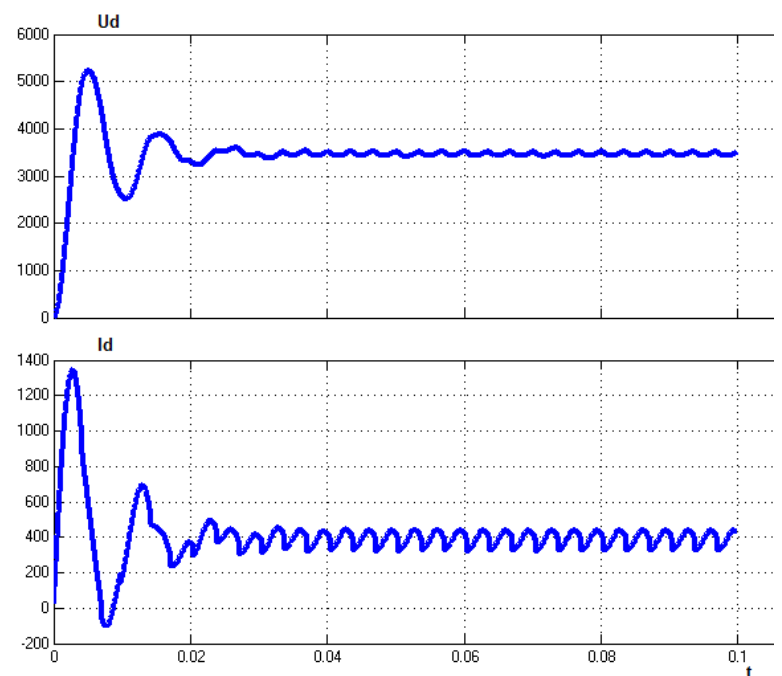

Fig. 7. Oscillogramme of the output current and voltage of the active rectifier with hysteresis control system.

The form of the input voltage and current can be improved by increasing inductance of the input filter of the active rectifier. As is seen, the diagrams of the output voltage and current of the active rectifier with the same parameters of the model elements indicate overcontrol of these parameters as absence of pulse-width modulation reduces speed-performance of control over output voltage of the self-commutated rectifier.

To reduce voltage overcontrol, the control system and the output voltage controller are to be readjusted. The time of the output voltage increase to reach the set value makes $0.02 \mathrm{sec}$, the pulse number of the rectifier scheme is $\mathrm{m}=6$.

The curves of input currents of the active rectifier with the hysteresis control system have significant deviations as compared with the active rectifier with the pulse-width modulation control system. The form of these parameters can be improved by changing parameters of the input filter of the active rectifier. 


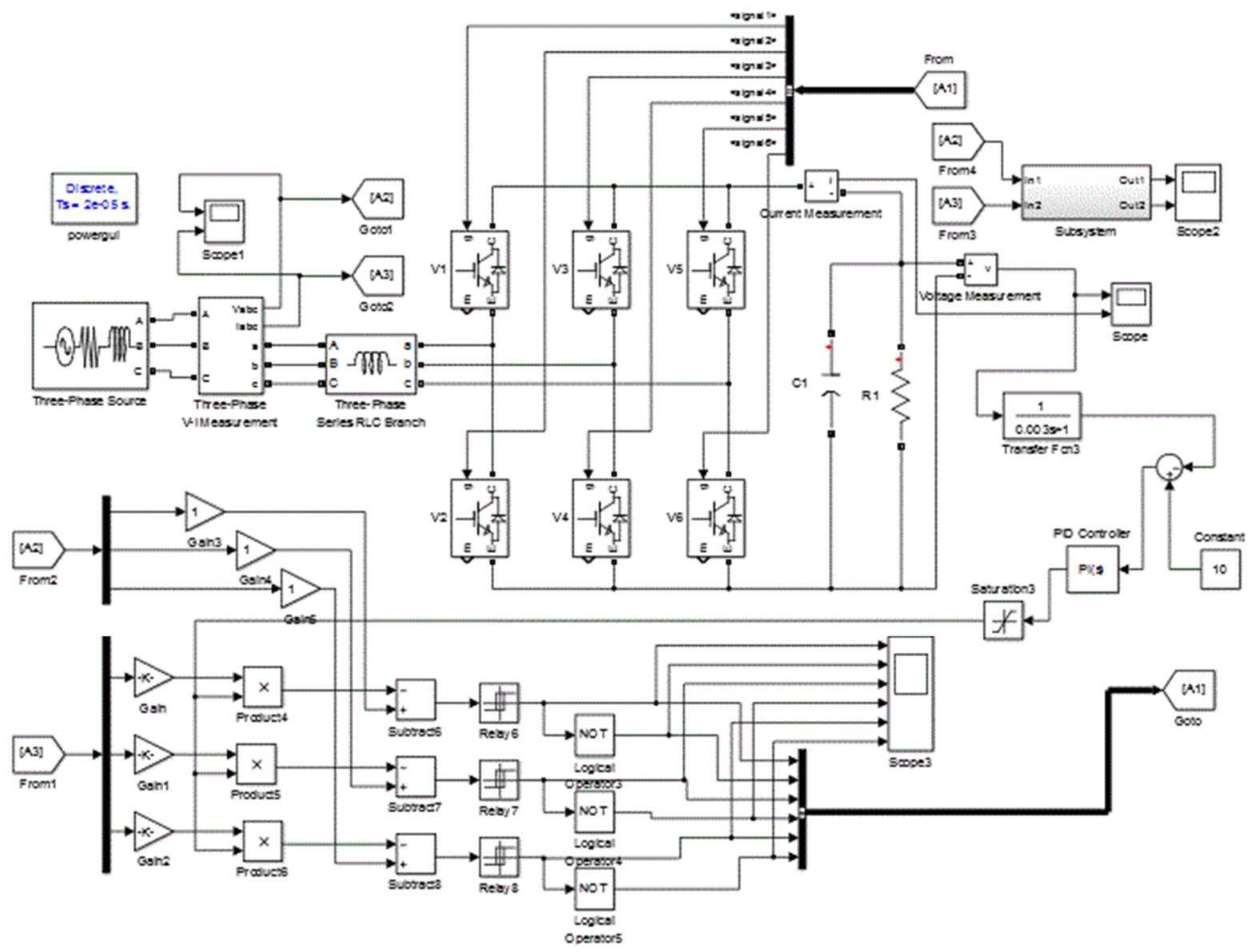

Fig. 6. Diagram of the active rectifier model with the hysteresis control system.

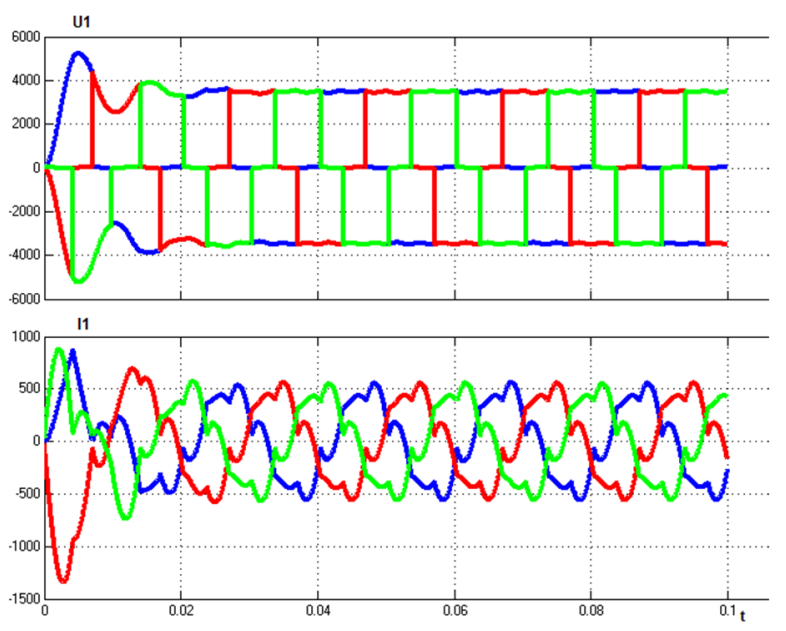

Fig. 8. Oscillogramme of the output current and voltage of the active rectifier with the hysteresis control system.

Fig. 9 shows oscillogrames of active and reactive power of the active rectifier.

Pulsations of signals of active and reactive power are conditioned by pulsations of the input voltage and current. To use these signals as feedbacks, it is necessary to set corresponding filters.

There are MATLAB researches into the drive model of the FC-SM system with the active rectifier. Fig. 10 presents a drive model with the active rectifier.

This model has units of the three-phase voltage source, the three-phase voltage and current meter, the self-commutated synchronous motor with subsystems of the synchronous motor, the rectifier, the DC chain, the invertor, the speed controller, the rectifier controller and the vector controller, the demultiplexor of motor parameters and the calculator of active and reactive power from the grid.

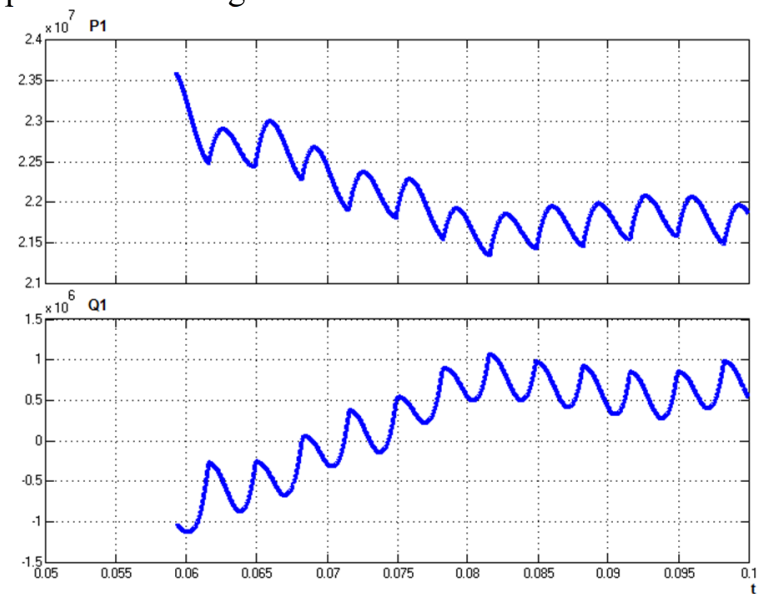

Fig. 9. Oscillogramme of active and reactive power of the active rectifier.

Fig. 11 contains diagrams of the rotor speed of the synchronous motor, electromagnetic torque, active and reactive power. This model reduces reactive power from the grid. The reaction of the drive to load surge and changes of consumed active and reactive power are studied. As is seen from the speed diagram the astatic control system after the load surge reacts to dynamic speed slumps and monitors the signal by the speed. The diagram of consumed active power is determined by the motor speed and torque. Reactive power is minimal and 
provides the power factor close to one. The system is also able to generate reactive power. The system has four control channels - by the input reactive current of the active invertor, by the set output voltage of the active rectifier, by frequency and the pulse ratio of the invertor voltage.

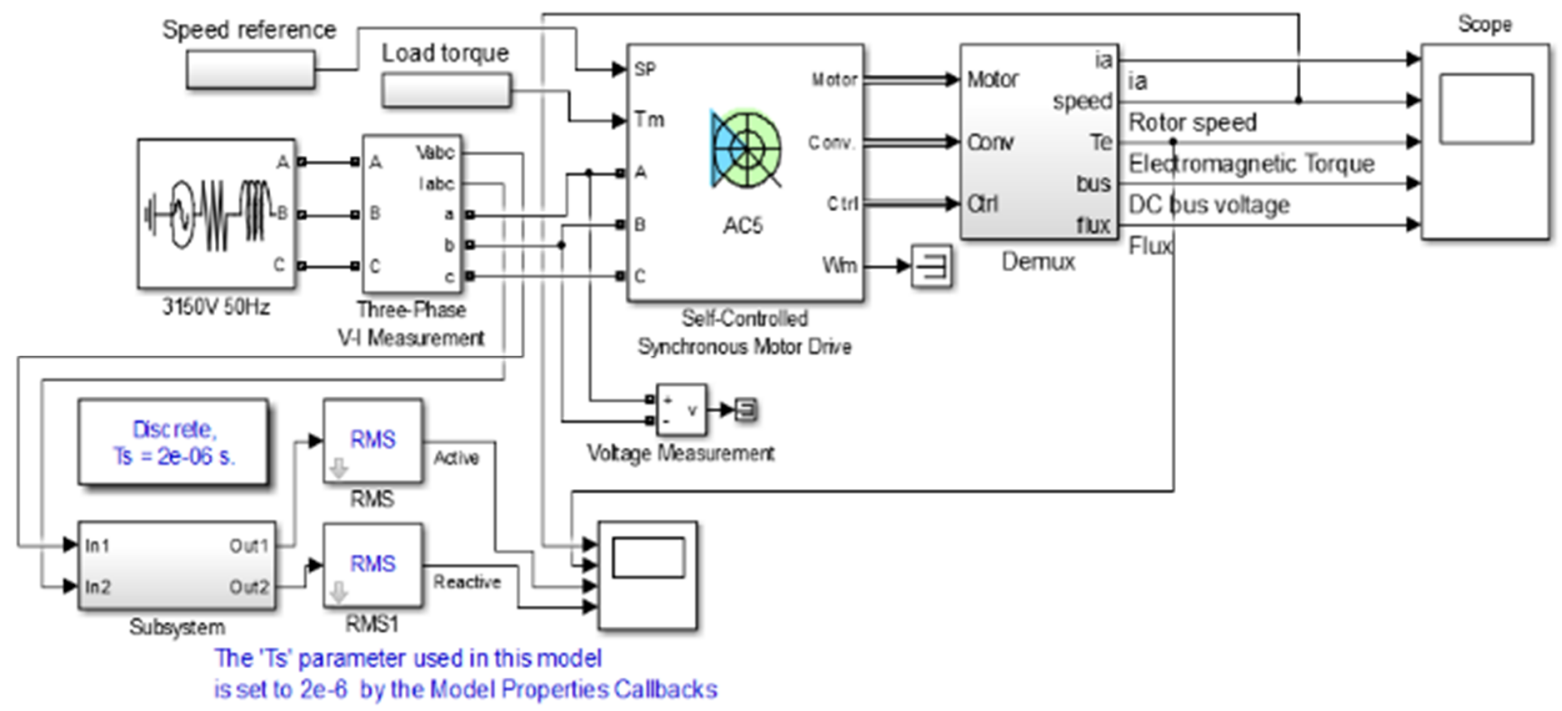

Fig. 10. Diagram of the drive model with the FC-SM.
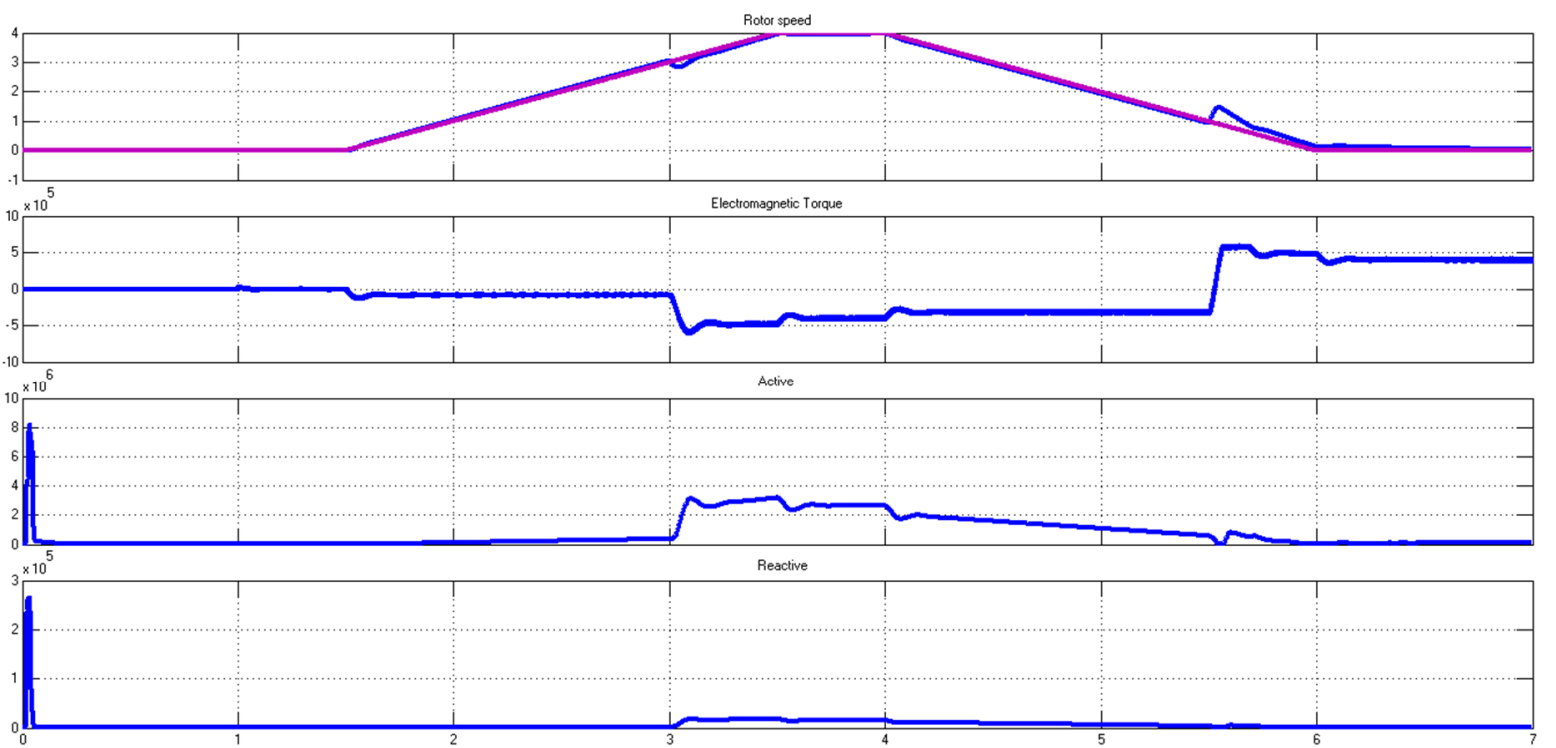

Fig. 11. Oscillogramme of rotation speed, active and reactive power of the FC-SM.

\section{Conclusions}

The research investigates into specific features of applying active rectifiers to frequency-controlled drives of underground mine hoists. Corresponding models are developed and studied to compare and analyze two types of control over transistor switches of the active rectifier. Analysis of the active rectifier mode enables determining advantages and disadvantages of these control systems and formulating requirements to improving parameters of the active rectifier. The structure of the control system of the frequency convertor is also analyzed, this indicating a potential control over torque controllers, the motor flux, the level of consumed reactive power and the power factor value.

Application of the research results will allow determining structures and methods of adjustment of control systems of the active rectifier in the frequencycontrolled drive of underground mine hoists. The scope of further research will involve improvement of energy efficiency of active rectifiers and reduction of their impact on the grid.

\section{References}

1. O. Sinchuk, Yu. Filipp, M. Maksimov, R. Zaytsev, The effects of adjustable electric drives of mine hoisting equipment on the electricity quality in the power supply circuits, Electromechanical and energy saving systems, Kremenchuk Mykhailo Ostrohradskyi National University, 1, 49-55 (2017)

2. I. Sinchuk, E. Guzov, A. Yalovaya, S. Boyko, Potential of electric power efficiency and ways of its implementation in production sectors with 
underground methods of iron ore extraction, P.H. Shcherbatykh A.V., Kremenchuk (2015), p. 296

3. L. Datskovskiy, V. Rogovoy, Electric drive of mine stationary equipment, Electrical machine building and electrical equipment, Odessa, 66, 94-102 (2010)

4. V. Litvak, G. Markman, N. Harlov, Energy saving and electric power quality, Tomsk (2005), p. 157

5. O. Bilous, A. Saghizov, Mathematical modeling of the impact of direct frequency converter operation on the power supply circuit, Bulletin of Perm National Research Polytechnic University, Electrical Engineering, Information Technology, Control Systems, 8, 106-113 (2013)

6. L. Datskovskiy, V. Rogovoy, I. Kuznetsov, Electric drives of modern mine hoisting machines, Bulletin of Tula State University. Engineering sciences, 3, 157-165 (2010)

7. A. Chermalykh, A. Danilin, A. Bosak, A. Petruchenko, Reference-model combined operation of mine hoisting installation's positioning electric drive, Problems of energy and resource saving in electrical systems. Science, Education and Practice, Scientific publication, Kremenchuk Mykhailo Ostrohradskyi National University, 1, 29-31 (2016)

8. A. Bosak, V. Chermalykh, Positional control of the mine hoisting installation with a fuzzy correction of the load's location, Bulletin of the "Kharkiv Polytechnic Institute" of the National. 36, 485-487 (2013)

9. O. Plakhtii, V. Nerubatskyi, V. Kavun, D. Hordiienko, Active single-phase four-quadrant rectifier with improved hysteresis modulation algorithm, Naukovyi Visnyk Natsionalnoho Hirnychoho Universytetu, 5, 93-98 (2019)

10. Zhang Hongwei, Wang Xinhuan, YU Fashan, Research on the Operation Control for Rope-less hoist system Driven by Permanent Magnet Linear Synchronous Motor, Proceedings of the 31st Chinese Control Conference, July 25-27, 2012, Hefei, China, 5619-5624 (2012)

11. P. Borisov, A. Sednev, Mathematical simulation of the DC electric drive with the active rectifier, Nauchno-tehnicheskiy vestnik SanktPeterburgskogo gosudarstvennogo universiteta informatsionnyh tehnologiy, mehaniki i optiki, 3, 35-41 (2009)

12. Anjana Manuel, Jebin Francis. Simulation of Direct Torque Controlled Induction Motor Drive by using Space Vector Pulse Width Modulation for Torque Ripple Reduction. International Journal of Advanced Research in Electrical, Electronics and Instrumentation Engineering, 2, 4471-4478 (2013)

13. J. Lettl, J. Bauer. Compatibility of Different Types of Frequency Converters with Supply Network. Faculty of Electrical Engineering, Czech Technical University in Prague, Czech Republic, PIERS Online, 6, 537-541 (2010)

14. J. Bauer. Single-Phase Pulse Width Modulated Rectifier. Czech Technical University in Prague
Faculty of Electrical Engineering Technická, Acta Polytechnica, 48, 84-87 (2008)

15. Madhuri Saxena, Sanjeev Gupta, Simulation of Multipulse Converter for HarmonicReduction using Controlled Rectifier, International Journal of Science and Research (IJSR), India, 2, 260-264 (2013)

16. D. Casadei, F. Profumo, G. Serra, A. Tani, FOC and DTC: Two Viable Schemes for Induction Motors Torque Control, IEEE Transactions on power electronics, 17, 779-787 (2002)

17. D.Ghanbari, N.R.Abjadi, A.Ghanbari, Direct Torque and Flux Control of Five-PhaseInduction Motor Using Fuzzy Logic, International Journal of Innovative Research in Electrical, Electronics, Instrumentations and Control Engineering, 2, 21962202 (2014)

18. T. Swapna, M. Rakesh, Analysis of 2-Level and 3Level Inverter Fed Direct Torque Control of Induction Motor Drive, Research Inventy: International Journal of Engineering And Science, 5, 20-26 (2015)

19. Y. Zeinaly, Computationally Efficient Model Predictive Direct Torque Control, Automatic Cotnrol Group, Department of Signals and Systems, Chalmers University of Technology, Göteborg, Sweden, (2010), p. 72

20. I. Fedotov, V. Tikhonov, E. Veselkov, N. Seletskaya, The comparative analysis of energetic characteristics of variable-frequency characteristics of variable-frequency electric drives with direct torque control, Environment. Technology. Resources, Rezekne, Latvia Proceedings of the 10th International Scientific and Practical Conference, 1, 33-38 (2015)

21. Ravindra Pawar, Ashok Jhala, Direct Torque Control of Induction Motor Drives, International Journal of Advanced Research in Electrical, Electronics and Instrumentation Engineering, 5, 798-804 (2016) 